\title{
Building long-term marketing relationships: New perspectives on B2B financial services
}

\author{
E. Theron*, N.S. Terblanche and C. Boshoff \\ Department of Business Management, Stellenbosch University, \\ Private Bag X1, Matieland 7602, Republic of South Africa \\ et3@sun.ac.za
}

\begin{abstract}
The focus of this study was on the relevance of trust, satisfaction and commitment in maintaining a long-term relationship (intention to stay) with an exchange partner in a Business-to-Business (B2B) context in the financial services industry. The perceptions of 238 B2B clients of a leading South African provider of development capital were investigated. Since support could not be found for the existence of trust, commitment and satisfaction as distinct individual dimensions, this study provides empirical support for the amalgamation of some well-established individual dimensions into broader, more holistic dimensions as drivers of long-term relationship building.

Contrary to expectations, B2B banking clients participating in this study appeared to regroup individual dimensions, in a heuristic fashion, to form new dimensions that influenced their attitude towards staying in a B2B relationship. As a result, building long-term marketing relationships seems to be a less complicated process than previously thought. Against this background, the primary contribution of the study is that it highlights the need for marketing practitioners to reconsider their current relationship-marketing strategies. As the findings of the study are inconsistent with conventional wisdom, they also challenge marketing academics to reconsider the theoretical foundations of relationship building in a B2B context.
\end{abstract}

*To whom all correspondence should be addressed.

\section{Introduction}

The combination of an increasingly competitive business environment and rising customer expectations has prompted many marketing academics and practitioners to pursue new, innovative ways to serve their customers. Although this objective can be realised in different ways, the implementation of relationship marketing has found general acceptance (Ndubisi \& Wah, 2005; Ward \& Dagger, 2007; Chattananon \& Trimetsoontorn, 2009).

Since its re-emergence in the early 1980 s, the concept of relationship marketing has been met with a great deal of enthusiasm (Kingshott \& Pecotich, 2007). Regardless of whether relationship marketing should be viewed as a new paradigm (Gummesson, 1997), or as a 'new-old' concept (Ballantyne, 1996), its benefits have seldom been questioned.

The acceptance of the relationship marketing concept has resulted in extensive research and wide implementation in a variety of industries. The financial services industry is no exception, and the use of relationship marketing principles to enhance customer relationships in this industry is well documented (Chiu, Hsieh, Li \& Lee, 2005; Roy \& Shekhar, 2010; Yap, Wong, Loh \& Bak, 2010).

After almost three decades of research, more recent events warrant a reconsideration of the concept of relationship marketing, especially some of the more generally-accepted conventions that have dominated the literature. For example, it is often assumed that a long-term marketing relationship can only be managed if exchange partners trust each other. But is this always the case? We know that the 2007-2009 global financial crisis has had a devastating effect on the way in which exchange partners perceive each other, and that the crisis has largely destroyed the heart of financial services relationships and trust in service providers (Ciobanu \& Bejou, 2009). Today, more than ever before, customers find it hard to decide who can still be trusted (Brencic, Pfajfar \& Raiakovic, 2012).

One may ask whether dimensions such as trust and commitment (often viewed as the cornerstones of a marketing relationship) should be stand-alone dimensions in the relationship marketing equation, or whether they are integrated as components of other dimensions - at least from a customer's perspective.

This study examined the relationship marketing literature from the perspective of the dimensions of a long-term marketing relationship. The relevance of a number of generally assumed dimensions was assessed in a financial services context, and the results were used to develop a framework that should guide the management of long-term marketing relationships in a B2B context. The results suggest that long-held beliefs about customer relationship management (CRM) may have to be reconsidered. 


\section{The importance of trust, commitment and intention to stay in a marketing relationship}

Despite extensive research since the early 1990's on the dimensions of relationship marketing, the marketing literature still lacks a comprehensive framework to guide the management of relationships in the long term. Although several studies have identified the dimensions of a marketing relationship, it appears that trust, commitment and intention to stay are more influential than other elements in sustaining long-term relationships (Morgan \& Hunt 1994; Wilson, 1995; Sin, Tse, Yau, Chow, Lee \& Lau, 2005).

Trust has always been viewed as a key construct in the development and management of long-term marketing relationships, and the concept has therefore been extensively researched (Dwyer, Schurr \& Oh, 1987; Morgan \& Hunt, 1994; Liang \& Wang, 2008). Based on the general support for the contention that trust is the cornerstone of a marketing relationship Mouzas, Henneberg and Naudé (2007) argue that trust is a significant, if not a pivotal, aspect of marketing relationships. From a marketing perspective, trust is defined as "confidence in an exchange partner's reliability and integrity" (Moorman, Deshpandé \& Zaltman, 1993: 83). As such, the concept implies that a relationship partner will fulfil promised role obligations (Dagger \& O'Brien, 2010). Trust not only plays a critical role in economic transactions to reduce perceived risk (Mukherjee \& Nath, 2007), but also lies at the heart of the marketing concept (Arnott, 2007).

The important role of trust in CRM has also been acknowledged as a key success factor in a wide variety of industries, such as financial services (Tyler \& Stanley, 2007), construction (Pinto, Slevin \& English, 2009), retail shopping (Wong \& Sohal, 2002), online auctions (Chiu, Huang \& Yen, 2010), courier delivery services (Rauyruen \& Miller, 2007), primary health care (Leisen \& Hyman, 2004) and advertising (Fam \& Waller, 2008). However, despite the increasing volume of research on the concept of trust, the insight and knowledge about this phenomenon are still limited when compared with other important concepts such as attitude (Sichtmann, 2007). Another source of concern is the fragmented nature of the literature related to trust $(\mathrm{Li}$, 2007), especially in a B2B context. Against this background, Doney, Barry and Abratt (2007) assert that there is a lack of research devoted to developing and testing a conceptual model that includes both the drivers and the outcomes of trust in a B2B services setting.

Another poorly understood concept in a CRM context is commitment. Commitment is defined by Gounaris (2005: 127) as "the desire for continuity manifested by the willingness to invest resources in a relationship", and the concept has served as the dependent variable in several relationship marketing models (Farrelly \& Quester, 2003). As commitment is viewed as a central construct in the relationship marketing literature, it has a crucial role to play in all the relational exchanges between a firm and its various stakeholders (Morgan \& Hunt, 1994). It is therefore not unexpected to find that commitment is regarded as a strategic component of a marketing relationship in a variety of industries, including commercial aviation (Barry, Dion \& Johnson, 2008), sales management (Schwepker \& Good, 2007), mobile services (Sahadev, 2008) and sponsorship (Farrelly \& Quester, 2003). However, few of these studies have investigated commitment in a B2B context.

Although commitment per se is sometimes viewed as the outcome of a marketing relationship, it can also be argued that a long-term relationship can only be maintained if it is characterised by both an expectation and a willingness to maintain the relationship (Anderson \& Weitz, 1989). Different terminology is used in the literature to describe this continuance of the relationship, such as "propensity to leave' (Morgan \& Hunt, 1994), 'anticipation of future interactions' (Crosby, Evans \& Cowles, 1990), 'relationship intentions' (Venetis, 1997) and 'behavioural intentions' (Gounaris, 2005). In order to integrate the multiple views on this topic, the present study used the concept 'intention to stay' as the outcome of a relationship, rather than commitment.

Trust and commitment are therefore modelled as key drivers of the intention to stay in a marketing relationship.

The marketing literature further suggests that trust, commitment and intention to stay should not be regarded as distinct dimensions, but rather as a coherent set of interactive dimensions. The relationship between trust and commitment, for example, is well accepted in the marketing literature, and the argument is that once exchange partners trust each other, they will be willing to commit themselves to the relationship (Razzaque \& Boon, 2003; Tellefsen \& Thomas, 2005; Caceres \& Paparoidamis, 2007). Furthermore, trust also has a positive effect on an exchange partner's intention to stay in a relationship, as does commitment (Gounaris \& Venetis, 2002; Johnson \& Grayson, 2005).

Based on the literature review, the following hypotheses are formulated:

$\mathrm{H}^{1 \mathrm{a}}$ There is a positive relationship between trust and commitment

$\mathrm{H}^{1 \mathrm{~b}}$ There is a positive relationship between trust and intention to stay

$\mathrm{H}^{1 \mathrm{c}}$ There is a positive relationship between commitment and intention to stay

\section{The antecedents of trust, commitment and intention to stay}

\section{Customer satisfaction}

Customer satisfaction is a major concern for all organisations, since it helps the latter to manage customer relationships more effectively through the different stages of the relationship (Ata \& Toker, 2012). Different definitions 
of customer satisfaction have been proposed. However, Rossomme (2003) points out that the concept of customer satisfaction in a B2B setting is different from that in a business-to-customer (B2C) context. Consistent with the definition of Anderson and Narus (1990: 45), customer satisfaction is viewed as a unidimensional construct in this study, and is operationalised as "a positive affective state resulting from the appraisal of all aspects of a firm's working relationship with another firm."

Although various antecedents of trust have been identified, customer satisfaction appears to be one of the most frequently cited precursors of trust (Leisen \& Hyman, 2004; Dabholkar \& Sheng, 2012; Hansen, 2012). Hansen (2012) as well as Po-Young, Gin-Yuan and Yu (2012) propose that, from a financial services perspective, customer satisfaction significantly influences trust in a relationship.

Customer satisfaction is widely accepted as a strong predictor of behavioural variables such as repurchase intentions (Mousa \& Zoubi, 2011). The basic premise of this argument is that the more satisfied a customer is with a relationship, the more likely it is that he/she will remain in the relationship (Peng \& Qing, 2006; Han, Back \& Barrett, 2009).

Based on this discussion of the literature, the following hypotheses are proposed:

$\mathrm{H}^{2 \mathrm{a}}$ There is a positive relationship between satisfaction and trust

$\mathrm{H}^{2 b}$ There is a positive relationship between satisfaction and intention to stay

\section{Communication}

According to Holden and O'Toole (2004), effective communication is the lifeblood and circulatory system of a marketing relationship. It is therefore not surprising that Kodish and Pettegrew (2008) view effective communication as one of the most prominent dimensions of a long-term marketing relationship. According to Hartmann (2010) forthright, two-way communication is a necessity for maintaining a long-term, productive relationship with a client, while Hennig-Thurau (2000) concludes that effective communication improves the quality of a relationship.

The marketing literature provides ample support for the effect of communication on trust (Kang, Jeon, Lee, \& Lee, 2005; Doney et al., 2007; Kyriazis, Couchman \& Johnson, 2012). Although conducted in different contexts, the core finding of each of these studies is that once service providers can succeed in increasing the effectiveness of communication in a relationship, it will result in increased trust between all the parties involved in the relationship. However, trust can only be fostered once communication is timely (Morgan \& Hunt, 1994) and effective (Adamson, Chan \& Handford, 2003).
Communication also influences an exchange partner's commitment to a relationship (Mathieu \& Zajac, 1990; Goodman \& Dion, 2001; Adamson et al., 2003). Meek, Davis-Sramek, Baucus and Germain (2011) argue that, particularly in a buyer-supplier relationship, collaborative communication creates a sense of community, which in turn positively affects commitment. This finding concurs with an earlier finding by Mathieu and Zajac (1990) that effective communication is the most influential antecedent in predicting commitment.

Based on these reported findings the following hypotheses are addressed:

$\mathrm{H}^{3 \mathrm{a}}$ There is a positive relationship between effective communication and trust

$\mathrm{H}^{3 \mathrm{~b}}$ There is a positive relationship between effective communication and commitment

\section{Competence}

Competence is defined as "the degree to which business transactions meet performance expectations" (Perry, Cavaye \& Coote, 2002: 79). Competence relates to the perception a buyer has of a supplier's technological and general business skills (Ndubisi, Wah \& Ndubisi, 2007), and is also associated with the reliability of information provided by a specific individual or firm (Selnes, 1998). Although the concepts 'competence' and 'expertise' are related, Moorman et al. (1993) maintain that expertise instead focuses on an exchange partner's knowledge concerning a particular field, enabling the supplying firm to provide accurate answers to specific questions posed by the customer. According to Griese, Pick and Kleinaltenkamp (2012), service providers can benefit from their relationships with their individual suppliers and customers if they (the service providers) are regarded as being competent.

The marketing literature provides ample support for the positive effect of competence on trust in a relationship (Moorman et al., 1993). Competence constitutes perceived trustworthiness, which in turn leads to a customer's sense of trust (Shainesh, 2012). This contention is similar to the view of Janowicz-Panjaitan and Krishnan (2009) that trustworthiness is rooted in a trustee's competence.

Based on the above literature review, the following hypothesis is formulated:

$\mathrm{H}^{4}$ There is a positive relationship between competence and trust

\section{Customisation}

Customisation, which refers to a supplier's willingness to build a unique product to fit operations for a customer's evolving needs (Krishna, 2007), appears to be a cornerstone of customer relationship management (Lemon, White \& Winer, 2002; Freeland, 2003). It therefore plays an 
important role in the reduction of uncertainty and vulnerability (Moorman et al., 1993). As the demand for customised services increases, suppliers will have to be willing to make idiosyncratic investments in specialised equipment, and to adapt production processes to meet those demands (Yen, Wang \& Horng, 2011).

The willingness of a supplier to uniquely customise for the customer is one way a supplier shows that it can be trusted to respond to customer requirements. Buyers trust suppliers whom they perceive as having made distinct investments on their behalf (Johnson \& Zineldin, 2003). For this reason customers may use performance measures such as customisation to evaluate their level of trust in transactions (Mukherjee \& Nath, 2007). Prior research suggests that trusting relationships are characterised by the supplier's willingness to customise services to meet buyer requirements (Brownell \& Reynolds, 2002).

As an exchange partner's uncertainty and vulnerability are reduced through customisation, trust in the relationship increases (Moorman et al., 1993). It is therefore to be expected that the positive impact of customisation on trust is reasonably well accepted in the marketing literature (Gill, Flaschner \& Shachar, 2006; Komiak \& Benbasat, 2007; Coelho \& Henseler, 2012). The underlying argument is that if service providers are willing to customise their service offerings, the trust in the relationship will increase accordingly.

Based on the literature review, the following hypothesis is proposed:

$\mathrm{H}^{5} \quad$ There is a positive relationship between customisation and trust

\section{Switching costs}

Switching costs can be defined as "the sacrifices or penalties consumers feel they may incur in moving from one provider to the next" (Jones, Reynolds, Mothersbaugh \& Beatty, 2007: 337). Therefore, when exchange partners consider whether or not they should switch service providers, they assess the once-off costs that are associated with the process (Burnham, Frels \& Mahajan, 2003). In this way some customers are at times locked into a relationship with a service provider. Researchers agree that relationships between customers and service providers are often strongly influenced by the potential impact of economic and psychological switching costs (Han \& Ryu, 2012). As these costs increase, customers may decide to forego the opportunity of entering into a new relationship (Patterson \& Smith, 2001). Thus, switching costs enhance commitment to a relationship, which in turn increases repurchase intention (Kaur, Sharma \& Mahajan, 2012).

Based on the support in the marketing literature, the following hypothesis is proposed:
$\mathrm{H}^{6} \quad$ There is a positive relationship between switching costs and commitment

\section{Attractiveness of alternatives}

Attractiveness of alternatives is defined as "the client's estimate of the likely satisfaction available in an alternative relationship" (Sharma \& Patterson, 2000: 475). In situations where a limited number of attractive alternatives exist (or where the partner is not necessarily aware of the alternatives), it is possible that the client will remain committed to the relationship even if the relationship is perceived as less than satisfactory (Sharma \& Patterson, 2000).

Despite the support in the marketing literature for the relationship between attractiveness of alternatives and commitment, the strength of the relationship appears to be under dispute. For example, Ping (2003) and Andreassen and Olsen (2008) report a direct effect of attractiveness of alternatives on commitment, while Patterson and Smith (2001) only confirm a weak influence. Despite the disputed strength of this relationship, and based on the theoretical support, it is proposed that:

$\mathrm{H}^{7} \quad$ There is a positive relationship between attractiveness of alternatives and commitment

\section{Relationship benefits}

Increased levels of competition have necessitated that many service providers continuously add new service offerings in an effort to add value to customers' transactional benefits (Morgan \& Hunt, 1994). The purpose of a marketing relationship is to provide value to both exchange partners, and this value could be enhanced by providing new benefits for both parties (Dorai \& Varshney, 2012). Furthermore, if these benefits are viewed as valuable, and the exchange partners value each other's contribution, it should result in enhanced commitment to the relationship (Adamson et al., 2003).

Once exchange partners perceive the benefits of a relationship as mutually beneficial, they are likely to commit themselves to developing and maintaining it (Chen, Chen \& Yeh, 2003). It is therefore important for service providers to focus on creating new relational benefits for their customers on a continuous basis, which may include confidence benefits, social benefits and special treatment benefits (Conze, Bieger, Laesser \& Riklin, 2010).

The following hypothesis is based on the above literature review:

$\mathrm{H}^{8} \quad$ There is a positive relationship between relationship benefits and commitment 


\section{Dependence}

Dependence is the extent to which there is no equivalent or better alternatives available in the market, which may force exchange partners to work closely with each other (Gao, Sirgy \& Bird, 2005). Referring to the level of dependence, Anderson and Narus (1990) concur that mutually dependent relationships normally involve extensive personal interactions and resource integration. Andaleeb (1996) argues that, since an organisation's objective with a relationship is to achieve certain goals, the organisation needs to become dependent on certain parties. This need leads to dependence, which is thought to be central to explaining many channel sentiments and behaviours.

When one partner is dependent on another, he/she values the relationship and wants to maintain it, which forms the basis for a commitment to the relationship (Andaleeb, 1996). In distributor-manufacturer relationships, Goodman and Dion (2001) report that, whatever the source of dependence, distributors who perceive themselves as dependent on particular manufacturers, will display an increased level of commitment to those manufacturers' products and programmes. These results have been confirmed by De Ruyter and Wetzels (1999), who have found a positive relationship between interdependence and commitment.

Based on the theoretical support, the following hypothesis is considered:

$\mathrm{H}^{9} \quad$ There is a positive relationship between dependence and commitment

The 13 hypothesised relationships are presented in Figure 1.

\section{Methodology}

\section{Sampling}

This study was conducted in the South African financial services industry. The population of the study was clients of a leading South African provider of development capital. These clients were classified by the service provider as small and medium-sized businesses, and as being predominantly owner-operated.

The sample was drawn by selecting those clients who had access to email facilities. A list of 1260 client names was supplied by the financial services provider, and all these clients were included in the sample. Convenience sampling was thus used.

\section{Questionnaire design}

The 11 dimensions that were included in the theoretical model were empirically measured with a 48-item questionnaire. All items were sourced from a variety of established scales that were obtained from the marketing literature, and that have demonstrated sufficient evidence of reliability and validity. None of the items were self- generated. In the questionnaire the respondents had to indicate their perceptions of the participating service provider. The complete set of items appears in Appendix 1.

\section{Data collection}

The questionnaire was placed on a website, and the data were collected online over a period of three weeks. Two weeks were allowed for the completion of the questionnaire, after which a single follow-up was conducted in an effort to increase the response rate.

\section{Data analysis}

To assess the discriminant validity of the items and the questionnaire, an exploratory factor analysis was performed. Cronbach alphas were used to assess the internal consistency of the dimension scores and to identify unreliable items, while multiple regression analysis was used to analyse the proposed relationships shown in Figure 2.

\section{Empirical results}

\section{Response rate}

Of the initial 1260 clients who were invited to participate in the study, 238 clients completed the questionnaire, representing a response rate of $18,89 \%$. Although the response rate could have been marginally increased by means of multiple follow-up invitations to participate, it was decided to send one follow-up only. This decision was influenced by the service provider's insistence that the research should not cause any inconvenience to its clients.

Non-response bias was assessed by using the method suggested by Armstrong and Overton (1977), which proposes that the last cohort of respondents of a study can be used as a prediction of non-response. The data were divided into four quartiles based on demographic classifications, and one-way ANOVA tests were conducted to identify potential differences between the quartiles. No statistically significant differences could be found between the four quartiles in respect of any of the variables. It therefore appears that nonresponse bias was not prevalent in this study.

\section{Exploratory factor analysis}

In an attempt to avoid multicollinearity problems, the independent variables were subjected to an exploratory factor analysis (EFA) as suggested by Farrall (2010). A 0,5 loading was used as the cut-off point since all loadings above this level are considered practically significant (Siguaw, Simpson \& Baker, 1998). Principal axis factoring was used as the extraction method, while Direct Quartimin Oblique with Kaiser Normalisation was used as the rotation method. The results of the exploratory factor analysis appear in Table 1. 


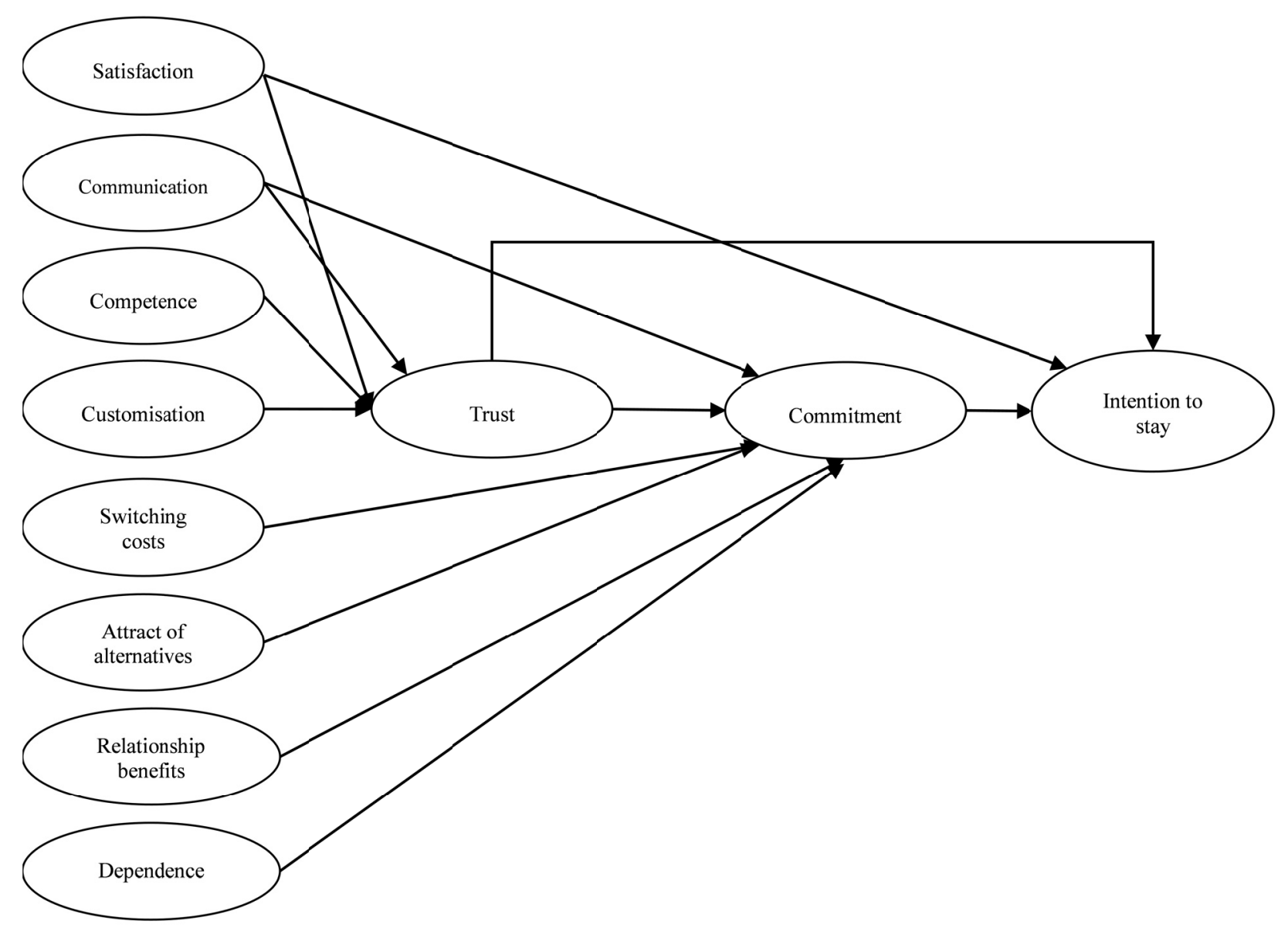

Figure 1: The hypothesised relationships

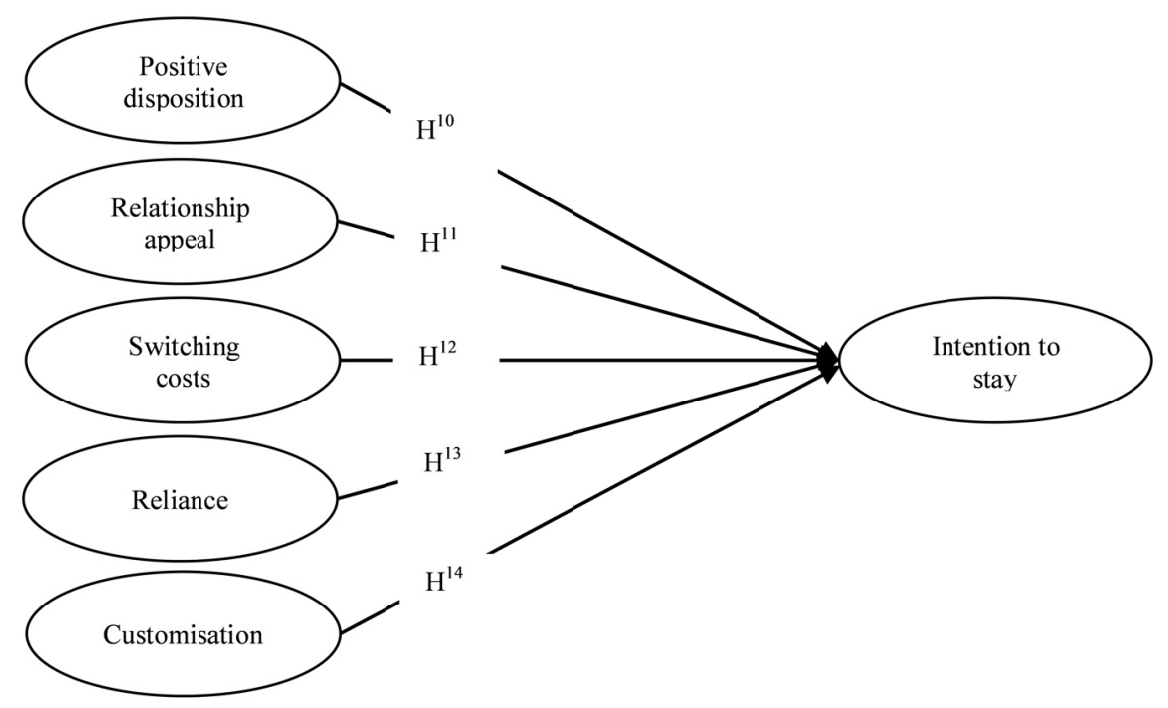

Figure 2: The new set of hypotheses 
Table 1: Results of the exploratory factor analysis

\begin{tabular}{|c|c|c|c|c|c|}
\hline Items & Positive disposition & Relationship appeal & $\begin{array}{c}\text { Factors } \\
\text { Switching costs }\end{array}$ & Reliance & Customisation \\
\hline COMIT1 & 0,920 & & & & \\
\hline TRUS1 & 0,888 & & & & \\
\hline COMIT2 & 0,882 & & & & \\
\hline TRUS2 & 0,841 & & & & \\
\hline SAT1 & 0,821 & & & & \\
\hline TRUS4 & 0,806 & & & & \\
\hline TRUS3 & 0,790 & & & & \\
\hline COMIT3 & 0,712 & & & & \\
\hline SAT2 & 0,696 & & & & \\
\hline SAT5 & 0,655 & & & & \\
\hline COMIT4 & 0,651 & & & & \\
\hline SAT3 & 0,605 & & & & \\
\hline DEP2 & & 0,874 & & & \\
\hline ALT3 & & 0,855 & & & \\
\hline ALT4 & & 0,778 & & & \\
\hline SWC2 & & 0,660 & & & \\
\hline SWC3 & & & 0,912 & & \\
\hline SWC4 & & & 0,677 & & \\
\hline DEP1 & & & & 0,810 & \\
\hline SWC1 & & & & 0,704 & \\
\hline DEP3 & & & & 0,515 & \\
\hline CUSTOM2 & & & & & 0,705 \\
\hline CUSTOM3 & & & & & 0,703 \\
\hline CUSTOM1 & & & & & 0,700 \\
\hline RBEN1 & & & & & 0,575 \\
\hline
\end{tabular}

An inspection of the factor matrix revealed some interesting results. Not only were the initial independent variables reduced to only five dimensions, but none of the initial dimensions emerged in their original form in the factor matrix. It was thus decided to rename the dimensions, with the following descriptions:

Factor 1, Postive disposition: This factor appeared to be a combination of the items used to measure trust, commitment and satisfaction, since 12 of the 13 items used to assess these three constructs loaded on this factor. The EFA therefore provided empirical evidence that the respondents regarded trust, commitment and satisfaction as a single construct. It was decided to label the new variable 'positive disposition', since all three the dimensions of trust, commitment and satisfaction implied a positive disposition towards a long-term marketing relationship with a service provider.

Factor 2, Relationship appeal: This factor consisted of two of the original 'attractiveness of alternatives' items, together with one each of dependence and switching costs. Based on the nature of the four items that constituted this factor, it appeared that the respondents preferred to engage in relationships that appealed to them.

Factor 3, Switching costs: Since the two items that constituted this factor originated from the original switching costs dimension, the 'switching costs' label was retained.

Factor 4, Reliance: This factor consisted of two items from the dependence variable and one from switching costs. From this configuration it was clear that respondents evaluated a financial services relationship in terms of the extent to which they felt that they could rely on the service provider.
The factor was therefore labelled 'reliance'. Although it may be argued that the concept of reliance is closely related to trust, Mouzas et al. (2007) believe that trust and reliance are independent and distinct characteristics of a relationship.

Factor 5, Customisation: This factor consisted of three items from the initial customisation variable together with one relationship benefits item. Consequently, it was decided to retain customisation as a label.

The initial set of hypotheses therefore had to be reviewed, and a new set of hypotheses was formulated.

$\mathrm{H}^{10}$ There is a positive relationship between positive disposition and intention to stay

$\mathrm{H}^{11}$ There is a positive relationship between relationship appeal and intention to stay

$\mathrm{H}^{12}$ There is a positive relationship between switching costs and intention to stay

$\mathrm{H}^{13}$ There is a positive relationship between reliance and intention to stay

$\mathrm{H}^{14}$ There is a positive relationship between customisation and intention to stay

The new hypotheses are graphically depicted in Figure 2.

As shown in Figure 2 and Table 2, positive disposition, relationship appeal, switching costs, reliance and customisation were modelled as the independent variables as antecedents of intention to stay in a B2B relationship. 
Table 2: Latent variables

\begin{tabular}{l|l}
\hline Dimensions & \multicolumn{1}{c}{ Manifest variables } \\
\hline Positive disposition & $\begin{array}{l}\text { TRUS1, TRUS2, TRUS 3, TRUS4, COMIT1, COMIT2, COMIT3, COMIT4, SAT1, SAT2, } \\
\text { SAT3, SAT5 }\end{array}$ \\
\hline Relationship appeal & DEP2, SWC2, ALT3, ALT4 \\
\hline Switching costs & SWC3, SWC4 \\
\hline Reliance & DEP1, DEP3, SWC1 \\
\hline Customisation & CUSTOM1, CUSTOM2, CUSTOM3, RBEN1 \\
\hline Intention to stay & INT1, INT2, INT3, INT4, INT5, INT6, INT7 \\
\hline
\end{tabular}

\section{Reliability}

The reliability scores of the scales used in this study ranged between 0,814 and 0,974. Since these scores are well above the customary cut-off point of 0,7 , the scores can be described as reliable (Nunnally \& Bernstein, 1994).

\section{Results of the regression analysis}

The results of the regression analysis are shown in Table 3.

Based on the $\beta$-value of 0,725 (Table 3 ), it was found that the dimension of positive disposition was the strongest predictor of intention to stay. Three further relationships were found to be significant: between relationship appeal and intention to stay ( $\beta$-value 0,144$)$, between switching costs and intention to stay ( $\beta$-value 0,127$)$, and between reliance and intention to stay ( $\beta$-value 0,073$)$. The relationships between relationship appeal and intention to stay, as well as between switching costs and intention to stay, were found to be significant on at least the 0,001 level, while the reliance was positively related to intention to stay on the 0,05 level. The results of the regression analysis consequently indicated support for hypotheses $\mathrm{H}^{10}, \mathrm{H}^{11}, \mathrm{H}^{12}$ and $\mathrm{H}^{13}$.

Only one hypothesised relationship (that between customisation and intention to stay) could not be confirmed. Hypothesis $\mathrm{H}^{14}$ therefore had to be rejected.

Based on the results in Table 3, multicollinearity did not seem to be a problem, since both the VIF and tolerance levels were within the generally accepted margins. The $\mathrm{R}^{2}$ value of 0,864 indicated that a considerable amount of the variance in intention to stay was explained by the five independent variables.

\section{Discussion}

Given the literature review and exploratory research, it was expected that the empirical findings would support many of the widely acknowledged relationships in the marketing literature. However, the findings of this study failed to do so; in fact, the results call for a reconsideration of some of the well-established conventions and general beliefs in the field of relationship marketing.

Firstly, it came as a surprise that (in a B2B financial services context) the respondents appeared to regroup or combine dimensions in order to simplify their decision-making process. For example, trust, commitment and satisfaction collapsed into a single construct. As a result, the relationships between trust and commitment, between satisfaction and trust, and between satisfaction and commitment could not be empirically assessed in this study. The empirical results thus question the generally assumed existence of trust, commitment and satisfaction as individual, distinct dimensions contributing to a long-term marketing relationship.

The results of this study could be explained by decisionmaking theories such as the Gestalt theory and heuristics. The Gestalt theory, for example, has as its basis the premise that a person's perceptions or experiences are made up of configurations of individual perceptions and experiences (Hoyt, 1944). The relevance of the Gestalt theory to the reported study could be seen in the overlap that was evident among some of the independent variables. During a service experience, financial services clients appear to disregard individual elements of such a service (in this case, individual dimensions), but regrouped the individual dimensions to establish new configurations of dimensions.

'Heuristics' refers to information-processing strategies, the so-called 'mental shortcuts' or 'rules of thumb' which are used systematically but often unconsciously, to simplify decision-making (Jordan \& Kaas, 2002). When consumers are faced with complex decision-making situations and/or when they are under time pressure, they tend to use heuristics to simplify the task (Lee \& Marlowe, 2003). In other words, heuristics are used in an attempt to reduce the mental effort involved in decision-making (Van Bruggen, Smidts \& Wierenga 1998). In this way clients simplify the decision-making process and distinguish between more and less important dimensions. 
Table 3: Results of the regression analysis

\begin{tabular}{l|c|c|c|c|c|c}
\hline Independent variables & Beta coefficients & t-values & $\begin{array}{c}\text { Level of } \\
\text { significance }\end{array}$ & VIF level & $\begin{array}{c}\text { Tolerance } \\
\text { level }\end{array}$ & $\begin{array}{c}\text { Remarks } \\
\text { Positive disposition }\end{array}$ \\
\hline Relationship appeal & 0,725 & 16,818 & 0,000 & 3,177 & 0,315 & $* * *$ \\
\hline Switching costs & 0,144 & 3,913 & 0,000 & 2,307 & 0,434 & $* * *$ \\
\hline Reliance & 0,127 & 4,168 & 0,000 & 1,578 & 0,634 & $* * *$ \\
\hline Customisation & 0,073 & 2,198 & 0,029 & 1,865 & 0,536 & $*$ \\
\hline
\end{tabular}

\begin{tabular}{ll}
\hline $\mathrm{R}^{2}=0.864$ \\
\hline \multicolumn{2}{l}{ Remarks: } \\
N.S. & not significant \\
$*$ & $\mathrm{p}<0,05$ \\
$* * *$ & $\mathrm{p}<0,001$
\end{tabular}

Exchange partners are drawn to a relationship based on the relative appeal that the relationship has for each of the partners. The support that was found in this study for the positive effect of relationship appeal on intention to stay, confirms this view. The competitiveness of the financial services industry makes it clear to service providers that they need to continuously reassess their offerings to clients. By ensuring that relationships appeal to customers, financial services providers could ensure that customers view the relationship as beneficial, and the attractiveness of the offerings of alternative service providers as less appealing.

The emergence of switching costs as a significant antecedent of an exchange partner's intention to stay in a relationship was not unforeseen, as it is consistent with the current marketing literature. Switching costs were assessed by focusing on the expenses that clients would incur if their financial services providers were switched. These expenses included both monetary costs (such as transactional costs) and non-monetary costs (in terms of wasted effort and time). The empirical confirmation of switching costs as a significant antecedent of intention to stay suggests a managerial dilemma: on the one hand, financial services providers should ensure that the switching costs that their customers would incur when changing service providers should be relatively high (to prevent clients from switching). On the other hand, high switching costs may be a hindering factor when clients have to select a financial services provider in the first instance.

$\mathrm{B} 2 \mathrm{~B}$ relationships are reliant on exchange partners to ensure the success of the relationships. As expected, support was found for the relationship between reliance and intention to stay. Although the nature of the reliance between B2B relationships can vary, all exchange partners are reliant on each other for the provision of limited resources (Mouzas et al., 2007). This limited availability of resources forms the basis for the Resource Dependence Theory, which has at its heart the firms' desire to gain access to valuable and often scarce resources (Pfeffer \& Salancik, 1978). If service providers succeed in gaining access to these resources, they may be in a better position to manage risk in uncertain environments (Singh, 2007).
The insignificant role of customisation in this study is particularly interesting, since this dimension appeared to be of lesser importance than was previously assumed. It shows that B2B clients are reconsidering the traditional role of financial services providers. It was indicated earlier that the 2007-2009 global financial crisis caused an erosion of trust in financial services providers. This attitude could result in clients applying a 'back to basics' approach, which implies that clients would only use financial services providers for the essential components of the service offered.

\section{Limitations}

This study needs to be replicated in order to confirm the validity of the final model. The well-established existence of trust, commitment and satisfaction as particular individual dimensions of a long-term marketing relationship is not questioned as such. The question is whether certain situations could exist where these three dimensions could be combined into a single dimension. The South African B2B financial services industry appears to be one of these unusual situations. However, further investigation is needed to confirm the generalisability of the results of this study.

\section{References}

Adamson, I., Chan, K. \& Handford, D. 2003. 'Relationship marketing: customer commitment and trust as a strategy for the smaller Hong Kong corporate banking sector', International Journal of Bank Marketing, 21(6/7): 347-358.

Andaleeb, S.S. 1996. 'An experimental investigation of satisfaction and commitment in marketing channels: the role of trust and dependence', Journal of Retailing, 72(1): 77-93.

Anderson, E. \& Weitz, B. 1989. 'Determinants of continuity in conventional industrial channel dyads', Marketing Science, 8(4): 310-323.

Anderson, J.C. \& Narus, J.A. 1990. 'A model of distributor firm and manufacturer firm working partnerships', Journal of Marketing, 54(1): 42-58.

Andreassen, T.W. \& Olsen, L.L. 2008. 'The impact of customers' perception of varying degrees of customer 
service on commitment and perceived relative attractiveness', Managing Service Quality, 18(4): 309-328.

Armstrong, J.S. \& Overton, T.S. 1977. 'Estimating nonresponse bias in mail surveys', Journal of Marketing Research, 16 (3): 396-402.

Arnott, D.C. 2007. 'Trust - current thinking and future research', European Journal of Marketing, 41(9/10): 981987.

Ata, U.Z. \& Toker, A. 2012 'The effect of customer relationship management adoption in business-to-business markets', Journal of Business \& Industrial Marketing, 27(6): 497-507.

Ballantyne, D. 1996. 'Getting your way in business', AsiaAustralia Marketing Journal, 4(1): 3-6.

Barry, J.M., Dion, P. \& Johnson, W. 2008. 'A cross-cultural examination of relationship strength in B2B services', Journal of Services Marketing, 22(2): 114-135.

Brencic, M.M., Pfajfar, G. \& Raiakovic, M. 2012. 'Managing in a time of crisis: marketing, HRM and innovation', Journal of Business \& Industrial Marketing, 27(6): 436-446.

Brownell, J. \& Reynolds, D. 2002. 'Strengthening the F\&B purchaser-supplier partnership: actions that make a difference', Cornell Hotel and Restaurant Administration Quarterly, 43(6): 49-61.

Burnham, T.A., Frels, J.K. \& Mahajan, V. 2003. 'Consumer switching costs: a typology, antecedents, and consequences', Journal of the Academy of Marketing Science, 31(2): 109121.

Caceres, R.C. \& Paparoidamis, N.G. 2007. 'Service quality, relationship satisfaction, trust, commitment and business-tobusiness loyalty', European Journal of Marketing, 41(7/8): 836-867.

Chattananon, A. \& Trimetsoontorn, J. 2009. 'Relationship marketing: a Thai case', International Journal of Emerging Markets, 4(3): 252-274.

Chen, H-G, Chen, E.T. \& Yeh, A. 2003. 'The effects of relationship commitment and trust on business to consumer electronic commerce - the case of Taiwan', Communications of the International Information Management Association, 3(1): 35-45.

Chiu, C-M., Huang, H-Y. \& Yen, C-H. 2010. 'Antecedents of trust in online auctions', Electronic Commerce Research and Applications, 9(2): 148-159.

Chiu, H-C., Hsieh, Y-C., Li, Y-C. \& Lee, M. 2005. 'Relationship marketing and consumer switching behaviour', Journal of Business Research, 58(12): 16811689.
Ciobanu, C. \& Bejou, D. 2009. 'Forging new global alliances: emerging markets and advanced economies', Journal of Relationship Marketing, 8(4): 280-298.

Coelho, P.S. \& Henseler, J. 2012. 'Creating customer loyalty through service customization', European Journal of Marketing, 46(3/4): 331-356.

Conze, O., Bieger, T., Laesser, C. \& Riklin, T. 2010. 'Relationship intention as a mediator between relational benefits and customer loyalty in the tour operator industry', Journal of Travel \& Tourism Marketing, 27(1): 51-62.

Crosby, L.A., Evans, K.R. \& Cowles, D. 1990. 'Relationship quality in services selling: an interpersonal influence perspective', Journal of Marketing, 54(3): 68-81.

Dabholkar, P.A. \& Sheng, X. 2012. 'Consumer participation in using online recommendation agents: effects on satisfaction, trust, and purchase intentions', The Service Industries Journal, 32(9): 1433-1449.

Dagger, T.C. \& O’Brien, T.K. 2010. 'Does experience matter? Differences in relationship benefits, satisfaction, trust, commitment and loyalty for novice and experienced service users', European Journal of Marketing, 44(9/10): 1528-1552.

De Ruyter, K. \& Wetzels, M. 1999. 'Commitment in auditor-client relationships: antecedents and consequences', Accounting, Organizations and Society, 24(1): 57-75.

Doney, P.M., Barry, J.M. \& Abratt, R. 2007. 'Trust determinants and outcomes in global B2B services', European Journal of Marketing, 41(9/10): 1096-1116.

Dorai, S. \& Varshney, S. 2012. 'A multistage behavioural and temporal analysis of CPV in RM', Journal of Business \& Industrial Marketing, 27(5): 403-411.

Dwyer, F.R., Schurr, P.H. \& Oh, S. 1987. 'Developing buyer-seller relationships', Journal of Marketing, 51(2): 1127.

Fam, K-S. \& Waller, D.S. 2008. 'Agency-client relationship factors across life-cycle stages', Journal of Relationship Marketing, 7(2): 217-236.

Farrell, A.M. 2010. 'Insufficient discriminant validity: a comment on Bove, Pervan, Beatty and Shin (2009)', Journal of Business Research, 63(3): 324-327.

Farrelly, F. \& Quester, P. 2003. 'The effects of market orientation on trust and commitment', European Journal of Marketing, 37(3/4): 530-553.

Freeland, J.G. 2003. The Ultimate CRM Handbook, New York: McGraw-Hill.

Gao, T., Sirgy, M.J. \& Bird, M.M. 2005. 'Reducing buyer decision-making uncertainty in organizational purchasing: 
can supplier trust, commitment, and dependence help?' Journal of Business Research, 58(4): 397-405.

Gill, A.S., Flaschner, A.B. \& Shachar, M. 2006. 'Factors that affect the trust of business clients in their banks', International Journal of Bank Marketing, 24(6): 384-405.

Goodman, L.E. \& Dion, P.A. 2001. 'The determinants of commitment in the distributor-manufacturer relationship', Industrial Marketing Management, 30(3): 287-300.

Gounaris, S.P. 2005. 'Trust and commitment influences on customer retention: insights from business-to-business services', Journal of Business Research, 58(2): 126-140.

Gounaris, S.P. \& Venetis, K. 2002. 'Trust in industrial service relationships: behavioural consequences, antecedents and the moderating effect of the duration of the relationship', Journal of Services Marketing, 16(7): 636655 .

Griese, I., Pick, D. \& Kleinaltenkamp. M. 2012. 'Antecedents of knowledge generation competence and its impact on innovativeness', Journal of Business \& Industrial Marketing, 27(6): 468-485.

Gummesson, E. 1997. 'Relationship marketing as a paradigm shift: some conclusions from the 30R approach', Management Decision, 35(3/4): 267-272.

Han, H., Back, K-J. \& Barrett, B. 2009. 'Influencing factors on restaurant customers' revisit intention: The roles of emotions and switching barriers', International Journal of Hospitality Management, 28(4): 563-572.

Han, H. \& Ryu, K. 2012. 'Key factors driving customers' word-of-mouth intentions in full-service restaurants: the moderating role of switching costs', Cornell Hospitality Quarterly, 53(2): 96-109.

Hansen, T. 2012. 'Understanding trust in financial services: the influence of financial healthiness, knowledge, and satisfaction', Journal of Service Research, 15(3): 280-295.

Hartmann, A.W. 2010. 'Building relationships to last', Journal of Financial Service Professionals, 64(1): 42-46.

Hennig-Thurau, T. 2000. 'Relationship quality and customer retention through strategic communication of customer skills', Journal of Marketing Management, 16(1-3): 55-79.

Holden, M. \& O'Toole, T. 2004. 'Affirming communication's primary role in a manufacturer-retailer context', Journal of Marketing Management, 20(9/10): 1047-1073.

Hoyt, E.E. 1944. 'The place of Gestalt theory in the dynamics of demand', American Journal of Economics and Sociology, 4(1): 81-85.
Janowicz-Panjaitan, M. \& Krishnan, R. 2009. 'Measures for dealing with competence and integrity violations of interorganizational trust at the corporate and operating levels of organizational hierarchy', Journal of Management Studies, 46(2): 245-268.

Johnson, D. \& Grayson, K. 2005. 'Cognitive and affective trust in service relationships', Journal of Business Research', 58(4): 500-507.

Johnson, P. \& Zineldin, M. 2003. 'Achieving high satisfaction in supplier-dealer working relationships', Supply Chain Management: An International Journal, 8(3): 224240.

Jones, M.A., Reynolds, K.E., Mothersbaugh, D.L. \& Beatty, S.E. 2007. 'The positive and negative effects of switching costs on relational outcomes', Journal of Service Research, 9(4): 335-355.

Jordan, J. \& Kaas, K.P. 2002. 'Advertising in the mutual fund business: the role of judgemental heuristics in private investors' evaluation of risk and return', Journal of Financial Services Marketing, 7(2): 129-140.

Kang, I., Jeon, S., Lee, S. \& Lee, C-K. 2005. 'Investigating structural relations affecting the effectiveness of service management', Tourism Management, 26(3): 301-310.

Kaur, G., Sharma, R.D. \& Mahajan, N. 2012. 'Exploring customer switching intentions through relationship marketing paradigm', Journal of Bank Marketing, 20(4): 280-302.

Kingshott, R.P.J. \& Pecotich, A. 2007. 'The impact of psychological contracts on trust and commitment in supplier-distributor relationships', European Journal of Marketing, 41(9/10): 1053-1072.

Kodish, S. \& Pettegrew, L.S. 2008. 'Enlightened communication is the key to building relationships', Journal of Relationship Marketing, 7(2): 151-176.

Komiak, S.Y.X. \& Benbasat, I. 2007. 'The effects of personalization and familiarity on trust and adoption of recommendation agents', MIS Quarterly, 30(4): 941-60.

Krishna, M. 2007. 'Realizing the value proposition of hosted DAM solutions: a case study', Journal of Digital Asset Management, 3(1): 50-4.

Kyriazis, E, Couchman, P. \& Johnson, L. 2012. 'Psychosocial antecedents of communication, trust and relationship effectiveness in new product development projects: a functional manager perspective', $R \& D$ Management, 42(3): 207-224.

Lee, J. \& Marlowe, J. 2003. 'How consumers choose a financial institution: decision-making criteria and heuristics', International Journal of Bank Marketing, 21(2): 53-71. 
Leisen, B. \& Hyman, M.R. 2004. 'Antecedents and consequences of trust in a service provider: the case of primary care physicians', Journal of Business Research, 57(9): 990-999.

Lemon, K.N., White, T.B. \& Winer, R.S. 2002. 'Dynamic customer relationship management: incorporating future considerations into the service retention decision', Journal of Marketing, 66(1): 1-14.

Li, P.P. 2007. 'Towards an interdisciplinary conceptualization of trust: a typological approach', Management and Organization Review, 3(3): 421-445.

Liang, C-J. \& Wang, W-H. 2008. 'Do loyal and more involved customers reciprocate retailer's relationship efforts?', Journal of Services Research, 8(1): 63-90.

Mathieu, J.E. \& Zajac, D.M. 1990. 'A review and metaanalysis of the antecedents, correlates, and consequences or organizational commitment', Psychological Bulletin, 108(2): 171-194.

Meek, W., Davis-Sramek, B., Baucus, M. \& Germain, R. 2011. 'Commitment in franchising: the role of collaborative communication and a franchisee's propensity to leave', Entrepreneurship: Theory and Practice, 35(3): 559-581.

Moorman, C., Deshpandé, R. \& Zaltman, G. 1993. 'Factors affecting trust in market research relationships', Journal of Marketing, 57(1): 81-101.

Morgan, R.M. \& Hunt, S.D. 1994. 'The commitment-trust theory of relationship marketing', Journal of Marketing, 58(3): 20-38.

Mousa, I. \& Zoubi, F. 2011. 'Exploring relationship marketing and marketing performance success: an empirical investigation in the insurance services sector from a management perspective', Amity Global Business Review, 6(1): 3-30.

Mouzas, S., Henneberg, S. \& Naudé, P. 2007. 'Trust and reliance in business relationships', European Journal Marketing, 41(9/10): 1016-1032.

Mukherjee, A. \& Nath, P. 2007. 'Role of electronic trust in online retailing: a re-examination of the commitment-trust theory', European Journal of Marketing, 41(9/10): 11731202 .

Ndubisi, N.O. \& Wah, C.K. 2005. 'Factorial and discriminant analyses of the underpinnings of relationship marketing and customer satisfaction', International Journal of Bank Marketing', 23(7): 542-557.

Ndubisi, N.O., Wah, C.K. \& Ndubisi, G.C. 2007. 'Suppliercustomer relationship management and customer loyalty: the banking industry perspective', Journal of Enterprise Information Management, 20(2): 222-236.
Nunnally, J. C. \& Bernstein, I. H. 1994. Psychometric Theory. 3rd edition. New York: McGraw-Hill.

Patterson, P.G. \& Smith, T. 2001. 'Modeling relationship strength across service types in an Eastern culture', International Journal of Service Industry Management, 12(2): 90-113.

Peng, L.Y. \& Qing, W. 2006. 'Impact of relationship marketing tactics (RMTs) on switchers and stayers in a competitive service industry', Journal of Marketing Management, 22(1/2): 25-59.

Perry, C., Cavaye, A. \& Coote, L. 2002. 'Technical and social bonds within business-to-business relationships', Journal of Business \& Industrial Marketing, 17(1): 75-88.

Pfeffer, J. \& Salancik, G.R. 1978. 'The External Control of Organizations: A Resource Dependence Perspective', New York: Harper and Row.

Ping, R.A. 2003. 'Antecedents of satisfaction in a marketing channel', Journal of Retailing, 79(4): 237-248.

Pinto, J.K., Slevin, D.P. \& English, B. 2009. 'Trust in projects: an empirical assessment of owner/contractor relationships', International Journal of Project Management, 27(6): 638-648.

Po-Young, C., Gin-Yuan, L. \& Yu, C. 2012. 'Service quality, customer satisfaction, customer trust, and loyalty in an e-banking context', Social Behavior \& Personality: An International Journal, 40(8): 1271-1283.

Rauyruen, P. \& Miller, K.E. 2007. 'Relationship quality as a predictor of B2B customer loyalty', Journal of Business Research, 60(1): 21-31.

Razzaque, M.A. \& Boon, T.G. 2003. 'Effects of dependence and trust on channel satisfaction, commitment and cooperation', Journal of Business-to-Business Marketing, 10(4): $23-45$.

Rossomme, J. 2003. 'Customer satisfaction measurement in a business-to-business context: a conceptual framework', Journal of Business \& Industrial Marketing, 18(2): 179-95.

Roy, S.K. \& Shekhar, V. 2010. 'Dimensional hierarchy of trustworthiness of financial service providers', International Journal of Bank Marketing, 28(1): 47-64.

Sahadev, S. 2008. 'Economic satisfaction and relationship commitment in channels', European Journal of Marketing, 42(1/3): 178-195.

Schwepker, C.H. \& Good, D.J. 2007. 'Exploring the relationships among sales manager goals, ethical behaviour and professional commitment in the sales force: implications for forging customer relationship', Journal of Relationship Marketing, 6(1): 3-19. 
Selnes, F. 1998. 'Antecedents and consequences of trust and satisfaction in buyer-seller relationships', European Journal of Marketing, 32(3/4): 305-322.

Shainesh, G. 2012. 'Effects of trustworthiness and trust on loyalty intentions: Validating a parsimonious model in banking', International Journal of Bank Marketing, 30(4): $267-279$.

Sharma, N. \& Patterson, P.G. 2000. 'Switching costs, alternative attractiveness and experience as moderators of relationship commitment in professional consumer services', International Journal of Service Industry Management, 11(5): 470-490.

Sichtmann, C. 2007. 'An analysis of antecedents and consequences of trust in a corporate brand', European Journal of Marketing, 41(9/10): 999-1015.

Siguaw, J.A., Simpson, P.M. \& Baker, T.L. 1998. 'Effects of supplier market orientation in distributor market orientation and the channel relationship: The distributor perspective', Journal of Marketing, 62(3): 99-111.

Sin, L.Y.M., Tse, A.C.B., Yau, O.H.M., Chow, R.P.M., Lee, J.S.Y. \& Lau, L.B.Y. 2005. 'Relationship marketing orientation: scale development and cross-cultural validation', Journal of Business Research, 58(2): 185-194.

Singh, V. 2007. 'Ethnic diversity on top corporate boards: a resource dependency perspective', International Journal of Human Resource Management, 18(12): 2128-2146.

Tellefsen, T. \& Thomas, G.P. 2005. 'The antecedents and consequences of organizational and personal commitment in business service relationships.' Industrial Marketing Management, 34(1): 23-37.
Tyler, K. \& Stanley, E. 2007. 'The role of trust in financial services business relationships', Journal of Services Marketing, 21(5): 334-344.

Van Bruggen, G.H., Smidts, A. \& Wierenga, B. 1998. 'Improving decision making by means of a marketing decision support system', Management Science, 44(5): 645658.

Venetis, K. 1997. 'Service Quality and Customer Loyalty in Professional Business Service Relationships', The Netherlands, University of Maastricht (PhD dissertation).

Ward, T. \& Dagger, T.S. 2007. 'The complexity of relationship marketing for service customers', Journal of Services Marketing, 21(4): 281-290.

Wilson, D.T. 1995. 'An integrated model of buyer-seller relationships', Journal of the Academy of Marketing Science, 23(4): 335-345.

Wong, A. \& Sohal, A. 2002. 'An examination of the relationship between trust, commitment and relationship quality', International Journal of Retail \& Distribution Management, 30(1): 34-50.

Yap, K.B, Wong, D.H., Loh, C. \& Bak, R. 2010. 'Offline and online banking - where to draw the line when building trust in e-banking?', International Journal of Bank Marketing, 28(1): 27-46.

Yen, Y., Wang, E.S. \& Horng, D. 2011.'Suppliers' willingness of customization, effective communication, and trust: a study of switching cost antecedents', Journal of Business \& Industrial Marketing, 26(4): 250-259. 


\section{APPENDIX 1}

\section{ITEMS USED TO MEASURE THE VARIABLES}

Note: FSP $=$ Financial Services Provider

Trust:

I trust my FSP.

I have confidence in my FSP.

My FSP can be regarded as credible.

My FSP demonstrates a high level of integrity.

\section{Commitment:}

I am committed to my FSP.

I really care to maintain my relationship with my FSP.

I am willing to invest time and other resources to maintain my relationship with my FSP.

I am willing to travel the extra mile to maintain my relationship with my FSP.

\section{Satisfaction:}

I am very satisfied with my FSP.

If I had to do it all over again, I would choose my FSP again.

I am satisfied with my FSP's products and services.

My FSP's service meets my expectations.

It is a pleasure to do business with my FSP.

\section{Communication:}

My FSP keeps me well-informed.

My FSP provides frequent communication about issues that are important to me.

My FSP provides timely information.

My FSP provides accurate information.

\section{Competence:}

My FSP is an expert FSP.

My FSP is an experienced FSP.

My FSP is knowledgeable about the provision of sophisticated financial services.

My FSP's staff are competent.

\section{Customisation:}

My FSP is flexible enough to accommodate any unforeseen problems I may experience.

My FSP can tailor its products/services to meet unexpected changes in my needs.

My FSP will quickly assist me if my needs change.

My FSP strives to offer me a customised service.

Attractiveness of alternatives:

The fees charged by my FSP are less than those of other banks.

My FSP offers a wider range of products and services than other banks.

There are not really worthwhile alternatives to my FSP.

It is questionable whether other banks can offer me a better service than my FSP.

\section{Relationship benefits:}

My FSP provides innovative solutions to meet my financial needs.

I benefit from my relationship with my FSP.

My relationship with my FSP enhances my income/revenue.

My relationship with my FSP helps me to take advantage of business opportunities.

\section{Switching costs:}

Considering all things, I would waste time if I did not use my FSP.

If I wish to change from my FSP, it is unlikely that I will find a provider as good as my FSP.

Switching to a new service provider will cost me money.

Changing service providers requires a lot of effort.

\section{Dependence:}

My business is dependent on my FSP.

It would be difficult for us to find an alternative to my FSP.

My FSP is crucial to our overall business performance.

My success in this business is largely due to the efforts of my FSP.

\section{Intention to stay:}

I expect to continue working with my FSP for a long time.

I intend to sustain my relationship with my FSP indefinitely.

I intend to continue to do business with my FSP.

I hope to do more business with my FSP.

Even if another FSP offered me lower fees I would not switch FSPs.

I do not have plans to switch banks in the near future.

I shall recommend my FSP's products and services to others. 